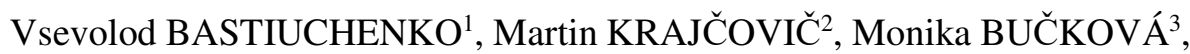 Olha KOLESNYK ${ }^{4}$
}

Supervisor: Martin KRAJČOVIČ́2

DOI: https://doi.org/10.53052/9788366249844.02

\section{Procedura PROJEKTOWANIA WDROŻENIA AUTOMATYCZNEJ LOGISTYKI}

\begin{abstract}
Streszczenie: Dzisiejsze firmy, kierując się wymogami Przemysłu 4.0, powinny aktywnie wykorzystywać i wdrażać w swojej produkcji narzędzia cyfrowej fabryki. W prezentowanym artykule opisano proces integracji zautomatyzowanej logistyki od fazy przygotowania do fazy wdrożenia zautomatyzowanej technologii na przykładzie samochodu ciężarowego AGV (Automated Guided Vehicle). Wyniki zamieszczone na końcu artykułu uzasadniają korzyści z zastąpienia pracy ludzkiej technologią zautomatyzowaną. Cały proces jest opisany na przykładzie rzeczywistego projektu, od fazy wstępnej do oceny rozwiązania.
\end{abstract}

Słowa kluczowe: koncepcja projektu, zautomatyzowana logistyka, wózek AGV.

\section{Procedure FOR DESIGNING THE IMPLEMENTATION OF AUTOMATED LOGISTICS}

Summary: Today's companies, following the requirements of Industry 4.0, should actively use and implement the tools of the digital factory in their production. The presented article describes the process of integration of automated logistics from the preparation phase to the implementation phase of automated technology, on the example of AGV (Automated Guided Vehicle) truck. The results published at the end of the article argue the advantages of replacing human labour with automated technology. The whole process is described on the example of a real project, from the initial phase to the evaluation of the solution.

Keywords: automated logistics, AGV truck, project design.

\footnotetext{
${ }^{1}$ Ing., University of Žilina, Faculty of Mechanical Engineering, Department of Industial Engineering, e-mail: vsevolod.bastiuchenko@fstroj.uniza.sk

2 prof., Ing., PhD., University of Žilina, Faculty of Mechanical Engineering, Deparment of Industrial Engineering, e-mail: martin.krajcovic@fstroj.uniza.sk

${ }^{3}$ Ing., PhD., University of Žilina, Faculty of Mechanical Engineering, Department of Industial Engineering, e-mail: monika.buckova@fstroj.uniza.sk

${ }^{4}$ Ing., University of Žilina, Faculty of Mechanical Engineering, Department of Industial Engineering, e-mail: olha.kolesnyk@fstroj.uniza.sk
} 


\section{Introduction}

In the current economic conditions, it is important to increase the efficiency of industrial enterprises. There are three main ways to increase the efficiency of their operation: improving technology and production, improving management organization, production logistics and business management. These methods require a significant investment of funds. Industrial enterprises should pay particular attention to improving the organizational processes of production and management, which can increase the competitiveness of the enterprise in the medium term [2]. The main sciences dealing with the improvement of these processes are management, marketing, logistics. When creating an automatic logistics system, several factors need to be taken into account, such as the type of material to be transported (dimensions, weight, shape), as well as the determination of loading and unloading locations, the determination of the circuit length and the like.

The article is divided into 3 parts:

- Initial phase of the project - important activities and information before the start of the project, data collection, evaluation.

- Automated logistics creation plan - material classification, design of supply routes, material flows.

- $\quad$ Results - comparison of the original state of logistics with automated logistics. The given article represents a company with a serial type of production.

\section{Project description}

A project is first and foremost a set of activities that need to be done in order to achieve a goal. This goal can be the construction of a house, moving, merging two companies into one, or in our case the improvement of production logistics, as well as the introduction of AGV technology [7].

For a successful implementation, it is necessary to go through several phases, which, of course, contain specific tasks. In addition to separate sources - financial, human, information, it is necessary to take into account the ways of communication between people, drawing up a plan, data collection, analysis, etc. The project procedure will be designed in the field of automated logistics. The analysis of the information will be described below.

\subsection{Initial phase of the project}

It is important to explain and describe the steps taken to begin the initial phase of automated logistics projects. The following methods are applied: observation, communication, creation of PFEP (Plan for every part) database and process map. At the beginning it is necessary to study the issue in order to know what to start from and what goals to achieve in the result.

\subsection{Observation}

The scientific method of observation is an urgent and useful thing in the initial phase of a project. The objects of observation were global - e.g. plant premises and in detail 
- e.g. production areas. The main focus is on the environment, people, data collection, planning of variants and communication.

\subsection{Communication}

For the most part, it is based on the verbal level of researchers and the respondent. The nature of communication is group. The interviews take place focusing on specific problematic situations, ways and ideas for solving them with the potential for improvement.

\subsection{Process map}

It is a more visually comprehensible and useful tool for illustrating the main and secondary information about the processes, goals, tasks to achieve them [4]. In the process of implementing an automated system, such a way of illustration can serve as a workflow for all project solvers, with which they can understand what stage they are in and why they will fulfil the given tasks.

\subsection{PFEP database}

PFEP needs to be updated and composed, as it often happens that information, e.g. parts are stored in different databases, so they are not grouped in one table. PFEP plan for every part, contains information for each of the parts: designation, PA (Production Area), weight, operating time, volume per change, specific operation, etc. This method helps to collect all important data in one database and save time, if we need to quickly find, analyse and compare one product or group of products, the easiest way to do it in Excel (Fig. 1). The detailed illustration shows us a complete picture of production.

\begin{tabular}{|c|c|c|c|c|c|c|c|c|c|c|c|}
\hline 1 & $\begin{array}{l}\text { Blok valca } \\
\text { Pump }\end{array}$ & 1350332 & $\begin{array}{l}\text { Cylinder } \\
\text { block }\end{array}$ & H1P69 & 11124482 & $3,00 \mathrm{~kg}$ & 325,20 sek & $83,03 \mathrm{ks}$ & $198,00 \mathrm{ks}$ & $594,00 \mathrm{~kg}$ & Polotovar \\
\hline 2 & $\begin{array}{l}\text { Blok valca } \\
\text { Pump }\end{array}$ & 1350332 & $\begin{array}{l}\text { Cylinder } \\
\text { block }\end{array}$ & H1P69 & 11124482 & $3,00 \mathrm{~kg}$ & 187,80 sek & $143,77 \mathrm{ks}$ & $198,00 \mathrm{ks}$ & $594,00 \mathrm{~kg}$ & $\begin{array}{l}\text { Puzdro } \\
\text { Wieland }\end{array}$ \\
\hline 3 & $\begin{array}{l}\text { Blok valca } \\
\text { Pump }\end{array}$ & 1350332 & $\begin{array}{l}\text { Cylinder } \\
\text { block }\end{array}$ & H1P69 & 11124482 & $3,00 \mathrm{~kg}$ & 187,50 sek & $144,00 \mathrm{ks}$ & $198,00 \mathrm{ks}$ & $594,00 \mathrm{~kg}$ & $\begin{array}{c}\text { Pružina Spring } \\
\text { helical }\end{array}$ \\
\hline 4 & $\begin{array}{l}\text { Blok valca } \\
\text { Pump }\end{array}$ & 1350332 & $\begin{array}{l}\text { Cylinder } \\
\text { block }\end{array}$ & H1P69 & 11124482 & $3,00 \mathrm{~kg}$ & 187,50 sek & $144,00 \mathrm{ks}$ & $198,00 \mathrm{ks}$ & $594,00 \mathrm{~kg}$ & $\begin{array}{l}\text { Podložka } \\
\text { Washer }\end{array}$ \\
\hline 5 & $\begin{array}{l}\text { Blok valca } \\
\text { Pump }\end{array}$ & 1350332 & $\begin{array}{l}\text { Cylinder } \\
\text { block }\end{array}$ & H1P69 & 11124482 & $3,00 \mathrm{~kg}$ & 187,50 sek & $144,00 \mathrm{ks}$ & $198,00 \mathrm{ks}$ & $594,00 \mathrm{~kg}$ & Artikel poistka \\
\hline 6 & $\begin{array}{l}\text { Blok valca } \\
\text { Pump }\end{array}$ & 1350332 & $\begin{array}{l}\text { Cylinder } \\
\text { block }\end{array}$ & H1P78 & 11124484 & $2,90 \mathrm{~kg}$ & 325,20 sek & $83,03 \mathrm{ks}$ & $198,00 \mathrm{ks}$ & $574,20 \mathrm{~kg}$ & Polotovar \\
\hline 7 & $\begin{array}{l}\text { Blok valca } \\
\text { Pump }\end{array}$ & 1350332 & $\begin{array}{c}\text { Cylinder } \\
\text { block }\end{array}$ & H1P78 & 11124484 & $2,90 \mathrm{~kg}$ & 196,20 sek & $137,61 \mathrm{ks}$ & $198,00 \mathrm{ks}$ & $574,20 \mathrm{~kg}$ & $\begin{array}{l}\text { Puzdro } \\
\text { Wieland }\end{array}$ \\
\hline 8 & $\begin{array}{l}\text { Blok valca } \\
\text { Pump }\end{array}$ & 1350332 & $\begin{array}{l}\text { Cylinder } \\
\text { block }\end{array}$ & H1P78 & 11124484 & $2,90 \mathrm{~kg}$ & $187,50 \mathrm{sek}$ & $144,00 \mathrm{ks}$ & $198,00 \mathrm{ks}$ & $574,20 \mathrm{~kg}$ & $\begin{array}{c}\text { Pružina Spring } \\
\text { helical }\end{array}$ \\
\hline 9 & $\begin{array}{c}\text { Blok valca } \\
\text { Pump }\end{array}$ & 1350332 & $\begin{array}{c}\text { Cylinder } \\
\text { block }\end{array}$ & H1P78 & 11124484 & $2,90 \mathrm{~kg}$ & 187,50 sek & $144,00 \mathrm{ks}$ & $198,00 \mathrm{ks}$ & $574,20 \mathrm{~kg}$ & $\begin{array}{l}\text { Podložka } \\
\text { Washer }\end{array}$ \\
\hline 10 & $\begin{array}{l}\text { Blok valca } \\
\text { Pump }\end{array}$ & 1350332 & $\begin{array}{l}\text { Cylinder } \\
\text { block }\end{array}$ & H1P78 & 11124484 & $2,90 \mathrm{~kg}$ & 187,50 sek & $144,00 \mathrm{ks}$ & $198,00 \mathrm{ks}$ & $574,20 \mathrm{~kg}$ & Artikel poistka \\
\hline 11 & $\begin{array}{l}\text { Blok valca } \\
\text { Pump }\end{array}$ & 1350332 & $\begin{array}{l}\text { Cylinder } \\
\text { block }\end{array}$ & H1P89 & 11124486 & $3,91 \mathrm{~kg}$ & 325,20 sek & $83,03 \mathrm{ks}$ & $135,00 \mathrm{ks}$ & $527,85 \mathrm{~kg}$ & Polotovar \\
\hline 12 & $\begin{array}{c}\text { Blok valca } \\
\text { Pump }\end{array}$ & 1350332 & $\begin{array}{c}\text { Cylinder } \\
\text { block }\end{array}$ & H1P89 & 11124486 & $3,91 \mathrm{~kg}$ & 247,20 sek & $109,22 \mathrm{ks}$ & $135,00 \mathrm{ks}$ & $527,85 \mathrm{~kg}$ & $\begin{array}{l}\text { Puzdro } \\
\text { Wieland }\end{array}$ \\
\hline 13 & $\begin{array}{l}\text { Blok valca } \\
\text { Pump }\end{array}$ & 1350332 & $\begin{array}{c}\text { Cylinder } \\
\text { block }\end{array}$ & H1P89 & 11124486 & $3,91 \mathrm{~kg}$ & 187,50 sek & $144,00 \mathrm{ks}$ & $135,00 \mathrm{ks}$ & $527,85 \mathrm{~kg}$ & Pružina Spring \\
\hline 14 & $\begin{array}{l}\text { Blok valca } \\
\text { Pump }\end{array}$ & 1350332 & $\begin{array}{l}\text { Cylinder } \\
\text { block }\end{array}$ & H1P89 & 11124486 & $3,91 \mathrm{~kg}$ & 187,50 sek & $144,00 \mathrm{ks}$ & $135,00 \mathrm{ks}$ & $527,85 \mathrm{~kg}$ & $\begin{array}{l}\text { Podložka } \\
\text { Washer }\end{array}$ \\
\hline
\end{tabular}

Figure 1. Sample PFEP database [Authors] 


\subsection{Project identification}

Project identification (Fig. 2) is the first stage of system design. The main task is to get acquainted with the company, find out the company's intentions, determine the problem and solution strategy and set up a solution team.

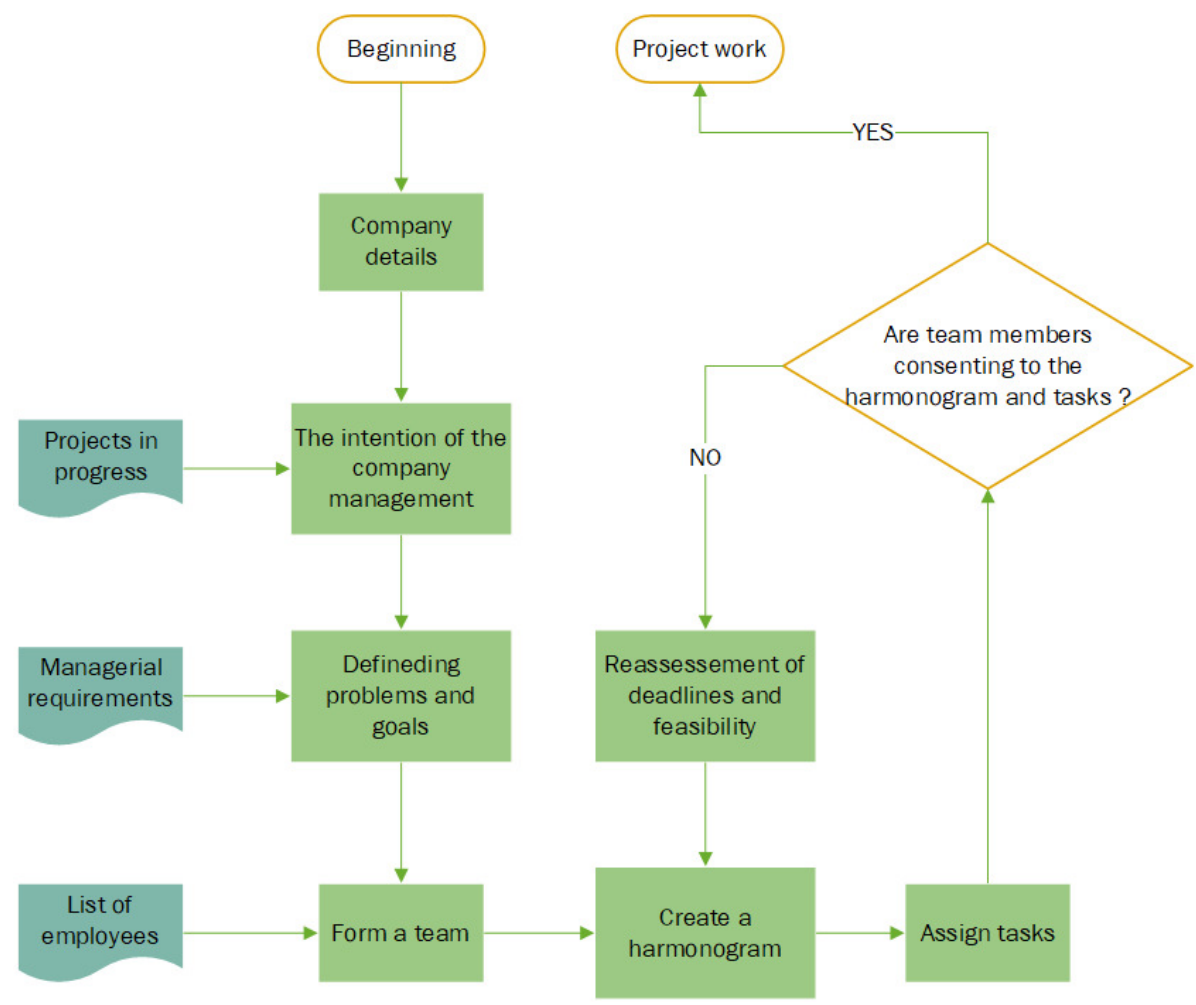

Figure 2. Project identification algorithm [Authors]

\subsection{Data collection}

It is necessary to know the accuracy of the obtained data, because it is the basis for creating and designing a logistics model [1]. If the data is correct, we can proceed to the creation of a database of products and components. The procedure from which it starts and how the data collection and processing continues is shown in the algorithm in the figure (Fig. 3).

\subsection{Process analysis}

A detailed analysis of all logistics processes and flows in the entire company and directly within the production areas will allow us to design automated logistics [5]. The given analysis was performed within the framework of a real project, therefore it is focused on areas in production - Central warehouse, Hardening, PA1, PA2, Dispatch warehouse. 


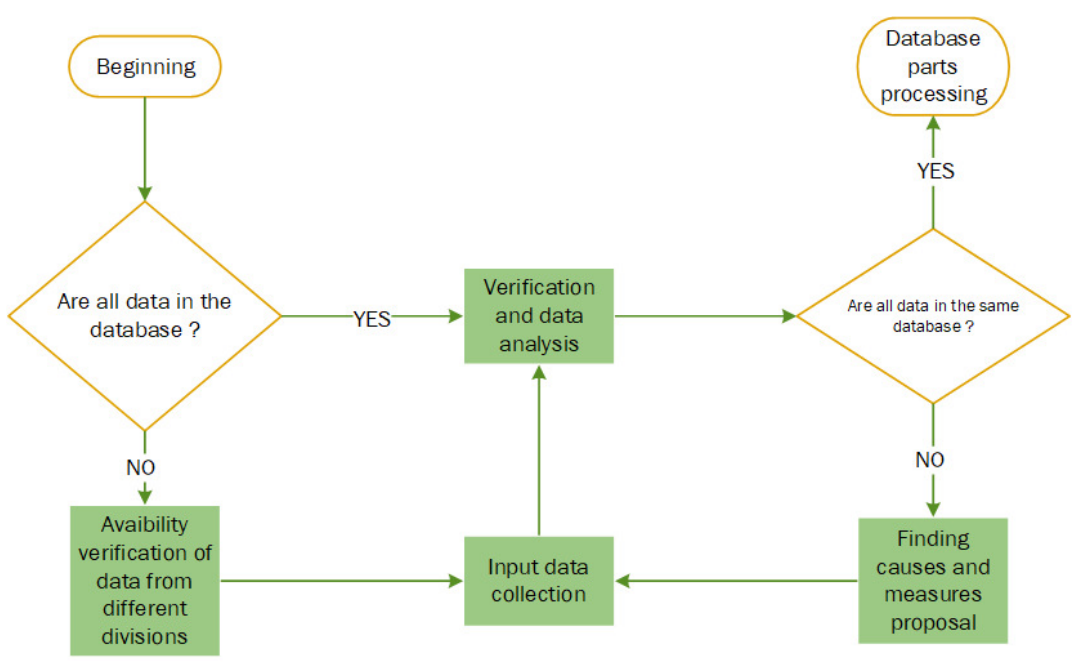

Figure 3. Data collection and processing algorithm [Authors]

Before designing an automated logistics system, the steps of the analysis procedure must be followed:

1. Find out the principle of functioning of the organizational structure of logistics (relations between departments and areas related to production).

2. Identify and verify the characteristics of the main transport relationships within the plant - (type of hall, tracks, curves, width and occupancy of streets).

3. In what way and where the material is ordered, received and stored - (suppliers, volume of batches, volume of production, warehouses).

4. Learn about the supply process of production areas and lines - (directions of material movement between areas and workplaces, supply intensity).

5. How to load and unload parts - (necessary to adapt AGV technology).

6. List of handling and transport equipment used throughout the plant (characteristics and method of work for the following comparison of advantages / disadvantages or connection to AGV technology).

7. Analysis of production areas related to the project - (understand the production technology in PA, such as the transport of products between workplaces in selected areas, the location of entry and exit points).

\section{Plan for the creation of automated logistics on the example of AGV}

This chapter progressively describes the design plan of a new logistics system in a selected plant for existing production. It is possible to see specific points, the gradual fulfilment of which will approach the successful implementation and achievement of the main goal:

1. Based on the PFEP database, it is possible to classify the transport of material (break down according to turnover).

2. Select the appropriate type of AGV (based on comparison, characteristics, material handling, dimensions and price). 
1. Identify translation input / output points that will be useful for material handling.

2. Create routes and directions for the AGV truck to move.

3. Dimension stocks.

4. Determine the degree of utilization of AGV (its static capacity calculations).

5. Demonstrate and verify design variants using selected planning software.

\subsection{Transport of material - classification}

The classification is based on the PFEP database. Input / output products and data should be divided into two separate tables, which show the transport volume and specific operations at the PA for better representation and further analysis.

\subsection{ABC classification}

Based on the data from the product database, it is necessary to create a graph in which we can see the ABC groups and the material items that belong to them (Fig. 4). It subsequently follows that all materials and finished products related to production in the selected areas can be divided into three groups according to the turnover of the items. This is necessary to select the appropriate product group that will serve the selected type of AGV truck. The groups and recommendations for selecting a suitable group for automatic transport are described below.

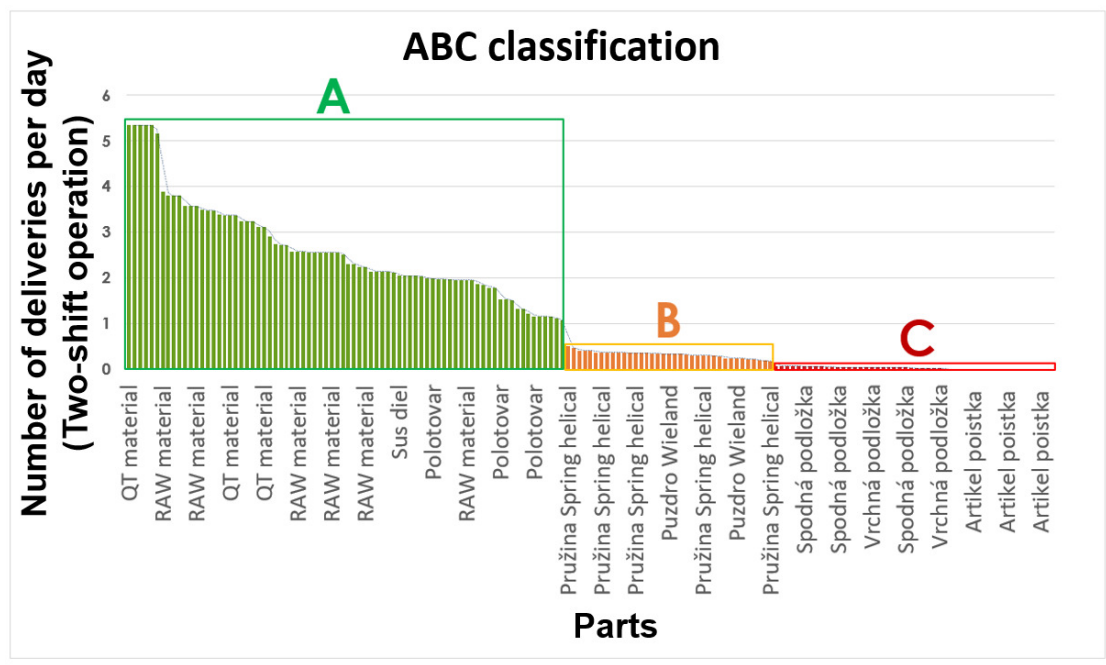

Figure 4. ABC classification of items in the chart view [Authors]

Group A is suitable for the application of automatic transport, because it consists of pallets that will be imported and consumed more than once a day as part of the production batch.

Group B has pallets that are imported from the income directly into the shelves of the production areas and will not be consumed per production batch. They will store the remaining material on the shelves of work in progress.

Group C represents non-patented material (springs, washers, fuses), they are imported in large volumes because they are small parts and have a long shelf life. From this we can say that the given group will not participate in automatic transport. 


\subsection{Design of supply routes}

When creating routes for $\mathrm{AGV}$ systems, in our case $\mathrm{AGV}$, it is important to incorporate all the specifics and restrictions in the company's premises [6].

If the important conditions for the installation of the system are met, it is possible to start with a pilot deployment of routes between the areas (Central Warehouse, Warehouse, PA1 / PA2, Dispatch Warehouse) related to the production of products. The figure (Fig. 5) shows all directions of movement of the selected AGV.

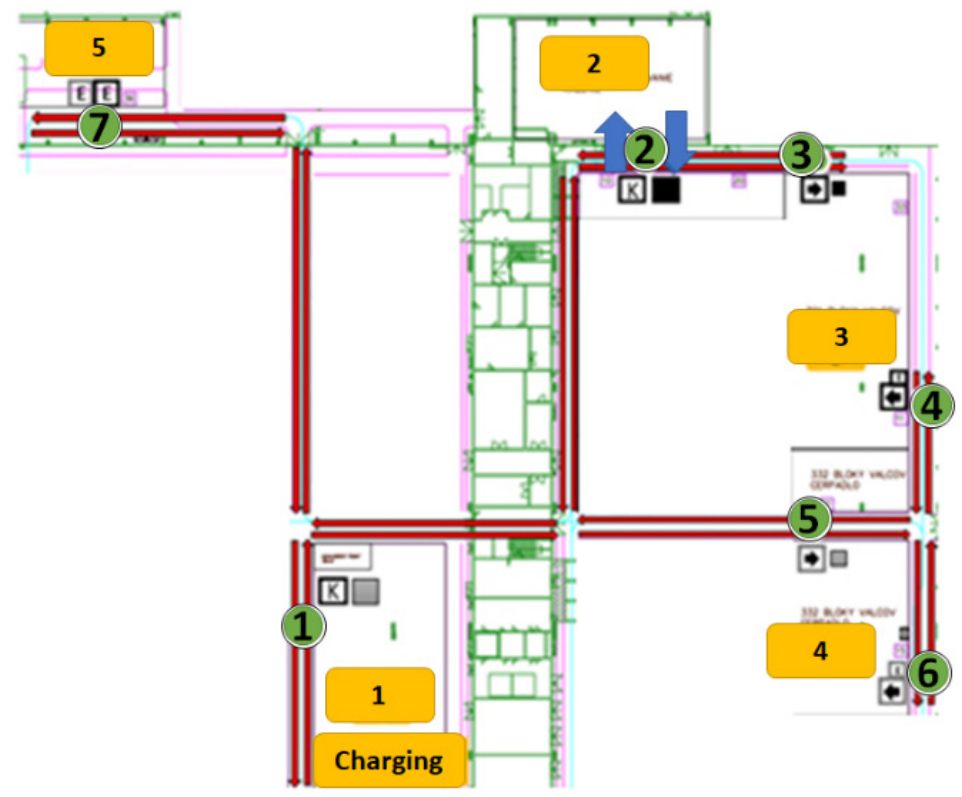

Figure 5. Supply circuit [Authors]

The next figure explains the important symbols (Fig. 6), which can be used to easily understand where the areas to which the transport has taken place, the input / output points

and the charging zone of the truck are located.

\section{One of the results of the project are the planned routes for the AGV truck:}

Route A - The process starts from the central warehouse. The length of the route after its measurement is $1077 \mathrm{~m}$. It passes through the interior of the hall with the material for hardening to the transfer point 2 (Hardening), in this place the material after hardening is also stored, which is consumed in PA1. The truck picks up the hardened material and takes it to the next place 3 (Input materials), from place 4 (Output materials), where the finished products are waiting for it, transports them to place 7 (Dispatch warehouse). The track then returns to CW (Central Warehouse).

Route B - Transport of funds for PA2. The length of the route after its measurement is $691 \mathrm{~m}$. Again, the process starts from $\mathrm{CW}$, where the trolley picks up the required pallet of material and goes towards position 5 (Input materials). According to another request, it will go to place 6 (Output materials), similar to the previous point (Route 
A), where it will load the machined products and transport them directly to place 7 (Dispatch warehouse). The track then returns to $\mathrm{CW}$.

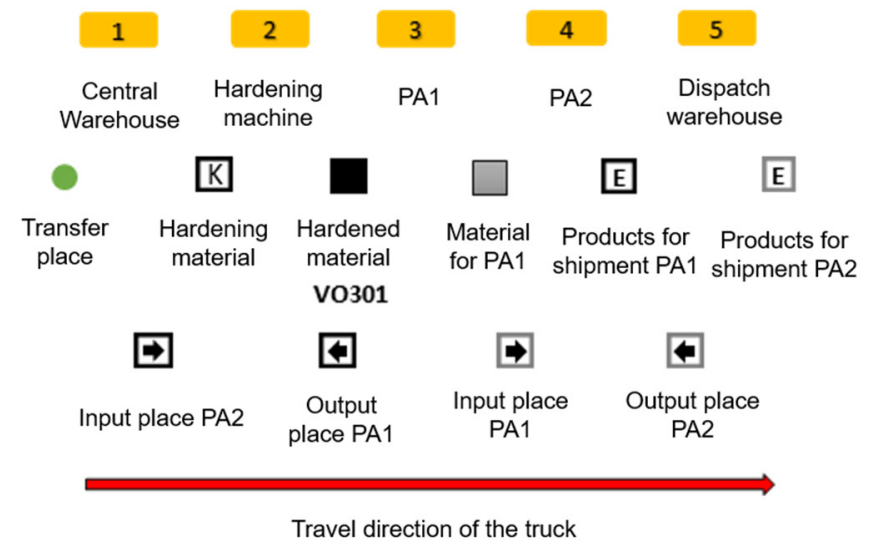

Figure 6. Description of symbols on the supply circuit [Authors]

\subsection{Table of material flows}

Material flows and their basic characteristics are processed and represented using a checkerboard table of traffic relations (Tab. 1). The table contains data on the successive places of loading and unloading of material according to the principle "from point A to point B", so also more detailed information about transport. It is one of the important additions that helps in the design and recalculation of equipment in the planning software.

Table 1. Chessboard table of transport relations [Authors]

\begin{tabular}{|c|c|c|c|c|c|c|c|c|c|}
\hline From & $\begin{array}{c}\text { Transfer } \\
\text { site }\end{array}$ & Where & $\begin{array}{c}\text { Transfer } \\
\text { site }\end{array}$ & $\begin{array}{c}\text { Pallets } \\
\text { /shift }\end{array}$ & $\begin{array}{c}\text { Pallets/day } \\
\text { (II - shifts) }\end{array}$ & $\begin{array}{c}\text { Palette } \\
\text { type }\end{array}$ & Material & $\begin{array}{c}\text { Weight of } \\
\text { the filled } \\
\text { pallet }\end{array}$ & $\begin{array}{c}\text { Palette } \\
\text { dimensions } \\
\text { [LxW] }\end{array}$ \\
\hline Warehouse & 1 & Hardening & 2 & 1,3 & 2,60 & EURO & RAW material & 482,2 & $1200 \times 800$ \\
\hline Hardening & 2 & PA1 & 3 & 2,6 & 5 & EURO & QT material & 538,1 & $1200 \times 800$ \\
\hline PA1 & 4 & $\begin{array}{c}\text { Expedition } \\
\text { warehouse }\end{array}$ & 7 & 0,8 & 1,60 & EURO & $\begin{array}{c}\text { Turned } \\
\text { product }\end{array}$ & 657,9 & $1200 \times 800$ \\
\hline $\begin{array}{l}\text { Expedition } \\
\text { warehouse }\end{array}$ & 7 & Warehouse & 1 & 0 & 0 & EURO & Empty & 0 & $1200 \times 800$ \\
\hline Warehouse & 1 & PA2 & 5 & 1,6 & 3,2 & EURO & $\begin{array}{c}\text { Semi-finished } \\
\text { product }\end{array}$ & 505 & $1200 \times 800$ \\
\hline PA2 & 6 & $\begin{array}{c}\text { Expedition } \\
\text { warehouse }\end{array}$ & 7 & 0,48 & 0,96 & EURO & $\begin{array}{c}\text { Machined } \\
\text { product }\end{array}$ & 882,2 & $1200 \times 800$ \\
\hline $\begin{array}{l}\text { Expedition } \\
\text { warehouse }\end{array}$ & 7 & Warehouse & 1 & 0 & 0 & EURO & Empty & 0 & $1200 \times 800$ \\
\hline
\end{tabular}

\section{Demonstration of further results}

The logic of the proposed flows is quite simple. The truck works according to the principle of requirements. This means that when, for example, new input material for 
PA1 is needed, there is a request for a CW. Immediately, the AGV truck responds and begins to complete the assigned task.

Every change, from Monday to Thursday, the truck transports a certain number of pallets along a specific route. On Friday, he is in charge of transporting the material, three times more than in previous days. This is due to the fact that the central warehouse does not operate on Saturdays and Sundays, while the production areas are in active condition and must meet the daily standard. After incorporating the planned design into the planning software, we can see information about the load capacity of the truck. (Tab. 2).

Table 2. Capacity recalculations of AGV truck utilization from Monday to Thursday (own processing) [Authors]

\begin{tabular}{|c|c|c|c|c|c|}
\hline Road & Distance [m] & Time [min] & $\begin{array}{l}\text { Total time [min] } \\
\text { (PA1/ PA2) }\end{array}$ & Workload [\%] & $\begin{array}{c}\text { Total workload [\%] } \\
\text { (PA1/ PA2) }\end{array}$ \\
\hline $\begin{array}{l}\text { CW-Hardening } \\
\text { machine-CW }\end{array}$ & 273,86 & 13 & \multirow[t]{3}{*}{53} & 2,91 & \multirow[t]{3}{*}{11,76} \\
\hline CW-PA1 (EP-CW) & 327,16 & 28 & & 6,26 & \\
\hline CW-PA1 (XP-EW-CW) & 475,81 & 12 & & 2,59 & \\
\hline CW-PA2 (EP-CW) & 216,41 & 14 & \multirow[t]{2}{*}{21} & 3,13 & \multirow[t]{2}{*}{4,68} \\
\hline CW-PA2 (XP-EW-CW) & 473,85 & 7 & & 1,55 & \\
\hline Sum & 1767,09 & & 74 & & 16,44 \\
\hline
\end{tabular}

Table 3. Capacity recalculations of AGV truck utilization on Friday [Authors]

\begin{tabular}{|c|c|c|c|c|c|}
\hline Road & Distance [m] & Time [min] & $\begin{array}{l}\text { Total time [min] } \\
\text { (PA1/ PA2) }\end{array}$ & Workload [\%] & $\begin{array}{l}\text { Total workload [\%] } \\
\text { (PA1/ PA2) }\end{array}$ \\
\hline $\begin{array}{l}\text { CW-Hardening } \\
\text { machine-CW }\end{array}$ & 273,86 & 18 & \multirow[t]{3}{*}{75} & 3,87 & \multirow[t]{3}{*}{16,43} \\
\hline CW-PA1 (EP-CW) & 327,16 & 39 & & 8,68 & \\
\hline CW-PA1 (XP-EW-CW) & 475,81 & 18 & & 3,88 & \\
\hline CW-PA2 (EP-CW) & 216,41 & 18 & \multirow[t]{2}{*}{29} & 3,9 & \multirow[t]{2}{*}{6,21} \\
\hline CW-PA2 (XP-EW-CW) & 473,85 & 11 & & 2,31 & \\
\hline Sum & 1767,09 & & 104 & & 22,64 \\
\hline
\end{tabular}

Table 4. Capacity calculations of a worker with a manual truck from Monday to Thursday (own processing) [Authors]

\begin{tabular}{|c|c|c|c|c|c|}
\hline Road & Distance [m] & Time [min] & $\begin{array}{l}\text { Total time [min] } \\
\text { (PA1/ PA2) }\end{array}$ & Workload [\%] & $\begin{array}{l}\text { Total workload [\%] } \\
\text { (PA1/ PA2) }\end{array}$ \\
\hline $\begin{array}{l}\mathrm{CW} \text {-Hardening } \\
\text { machine-CW }\end{array}$ & 273,86 & 15 & \multirow{3}{*}{61} & 3,2 & \multirow{3}{*}{13,53} \\
\hline CW-PA1 (EP-CW) & 327,16 & 32 & & 7,16 & \\
\hline CW-PA1 (XP-EW-CW) & 475,81 & 14 & & 3,17 & \\
\hline CW-PA2 (EP-CW) & 216,41 & 15 & \multirow{2}{*}{24} & 3,27 & \multirow{2}{*}{5,17} \\
\hline CW-PA2 (XP-EW-CW) & 473,85 & 9 & & 1,9 & \\
\hline Sum & 1767,09 & & 85 & & 18,7 \\
\hline
\end{tabular}

Table 5. Capacity calculations of a worker with a manual truck on Friday [Authors]

\begin{tabular}{|c|c|c|c|c|c|}
\hline Road & Distance $[\mathrm{m}]$ & Time [min] & $\begin{array}{l}\text { Total time [min] } \\
\text { (PA1/ PA2) }\end{array}$ & Workload [\%] & $\begin{array}{c}\text { Total workload }[\%] \\
\text { (PA1/ PA2) }\end{array}$ \\
\hline $\begin{array}{l}\text { CW-Hardening } \\
\text { machine-CW }\end{array}$ & 273,86 & 44 & \multirow{3}{*}{184} & 9,64 & \multirow{3}{*}{40,66} \\
\hline CW-PA1 (EP-CW) & 327,16 & 97 & & 21,5 & \\
\hline CW-PA1 (XP-EW-CW) & 475,81 & 43 & & 9,52 & \\
\hline CW-PA2 (EP-CW) & 216,41 & 17 & \multirow{2}{*}{43} & 3,68 & \multirow{2}{*}{9,37} \\
\hline CW-PA2 (XP-EW-CW) & 473,85 & 26 & & 5,69 & \\
\hline Sum & 1767,09 & & 227 & & 50,03 \\
\hline
\end{tabular}


The tables describe the process and results of the work of AGV (Tab. 3-4) in comparison with the classical manual track (Tab. 5-6). The total utilization from Monday to Thursday was $65.76 \%$, on Friday $22.64 \%$ for the AGV truck and $74.8 \%$, on Friday $50.03 \%$ for the manual truck. The average utilization rate of the former is set at $17.68 \%$ of the latter $24.96 \%$. At the same time, the import times of the automatic $\mathrm{AGV}$ truck are lower. It follows that it makes sense to replace human labor with automated technology.

\section{Conclusion}

The aim of the article was to describe the process of preparation and creation of automated logistics systems with the introduction of AGV trucks into the project of a real company. The sequence of the described steps helps to understand how a similar project is set up using an automated technique, what basic data should be collected and how to apply it. As a result, using this technique, it is possible to create a pilot or finished automated logistics project for the company. The collected data can be successfully imported into planning, modelling or simulation software [3].

\section{REFERENCES}

1. MALINDŽÁK D., TAKALA J.: Projektovanie logistických systémov (teória a prax). Košice : EXPRES PUBLIC s.r.o., 2005. 226 s. ISBN 88-8073-282-5.

2. GREGOR M.: Digitálny podnik. Žilina : Slovenské centrum produktívity, 2006. ISBN 80-969391-5-7.

3. BUBENÍK P., KADUCH P.: Vzdelávanie modelovacích techník prostredníctvom e-learningu. In: InvEnt 2006. Žilina: Žilinská univerzita, 2006. s. 160-165. ISBN 80-969391-1-4.

4. BARBUŠOVÁ M., BIGOŠOVÁ E., ČECHOVÁ I.: Systém merania productivity v podniku. In: Projekt interdyscyplinarny projektem XXI wieku. Monografia. Bielsko-Biała. Wydawnictwo Akademii Techniczno-Humanistycznej. 2018. ISBN 978-83-65182-92-0.

5. FURMANN R. Návrh algoritmu pre tvorbu výrobných dispozícií vo virtuálnom prostredí. Žilina : Žilinská univerzita $\mathrm{v}$ Žiline, Katedra priemyselného inžinierstva. Dizertačná práca, 2007.

6. TREBUŇA P., PEKARČÍKOVÁ M., KLIMENT M., TROJAN, J.: Metódy a systémy riadenia výroby $\mathrm{v}$ priemyselnom inžinierstve. Košice: Technická Univerzita v Košiciach, 2019. 210 s. ISBN 978-80-553-3280-2.

7. SVITEK R.: Návrh metodiky projektovania logistického systému v prostredí digitálneho dvojčat’a, Žilina. Dizertačná práca. Žilinská univerzita v Žiline, 2021. s. 128.

\section{ACKNOWLEDGMENT}

This article was created with support of VEGA 1/0248/21 - Research of innovative solutions for segmentation and sustainability of product regarding assembly operations. 